\title{
Uma ode ao ser humano
}

\section{Alberto Guzik}

$\int$

araíso Perdido é o mais bonito dos espetáculos em cartaz na cidade. E também o mais polêmico. Sua estréia na Igreja de Santa Ifigênia, apesar de autorizada pela Cúria Metropolitana, causou protestos de fanáticos. Mas, ao ver o espetáculo, constata-se que só a intransigência e a carolice seriam capazes de investir contra o trabalho de Antônio Araújo e do Teatro da Vertigem. Paraíso Perdido é uma ode ao ser humano e ao desejo de transcendência, que está na raiz de todo sentimento religioso.

Longe de ser irreverente ou profano, $\mathrm{Pa}$ raíso Perdido, adaptado do clássico poema que John Milton escreveu no século XVII, é um exercício de delicadeza e sensibilidade. A colocação da montagem numa igreja não é gratuita nem impensada. Falando de Deus, da alma, do sentimento de perda do Paraíso, de queda, era parte essencial do projeto sua encenação num templo. E a atitude esclarecida da Cúria e da Paróquia de Santa Ifigênia possibilitou ao público o acesso a uma obra de evidentes qualidades.

O poema original de John Milton, que muitos críticos comparam a William Shakespeare pelo vigor lírico, investiga os sentimentos do homem ante a perda da graça divina. Como a Divina Comédia, de Dante, Paraiso Perdido percorre os caminhos do inferno para chegar à possibilidade da redenção. Obra metafísica, onde a reflexão tem mais importância que a narrativa, a obra de Milton foi a fonte do espetáculo, mas na encenação esse eixo foi completado por citaçôes de Vicente Huidobro, J. L. Borges e T. S. Eliot.

O roteiro de Paraiso Perdido, articulado por Sérgio de Carvalho, é apaziguante e conciliatório. A dor e a revolta causadas pela expulsão do Éden levam à descoberta de que a aceitação da queda traz em si o caminho da redenção. Em tese, o roteiro poderia ter ousado mais no tratamento do tema, usando mais recursos ficcionais e menos narrativas didáticas. Diante da virulência dos protestos levantados pelo espetáculo, porém, entende-se a prudência do dramaturgo.

A montagem revela a força de Antônio Araújo, diretor jovem que demonstra domínio incomum da carpintaria do espetáculo. $\mathrm{O}$ encenador concebeu uma montagem processional. O público acompanha o Anjo Caido pela belíssima Igreja de Santa Ifigênia, transfigurada pela iluminação inspirada de Guilherme Bonfanti. A viagem assim realizada coloca o público em contato com as várias faces da humanidade

Alberto Guzik é crítico de teatro do Jornal da Tarde e pesquisador. 
desgraçada. E não há como ficar indiferente à beleza plástica do espetáculo, aos figurinos fantásticos de Fábio Namatame, à poderosa trilha sonora de Laércio Rezende, à emoção do elenco talentoso e apaixonado.

Paraíso Perdido pode ser visto sem susto por católicos, cristãos, muçulmanos, judeus, es- píritas e ateus. $\mathrm{O}$ espetáculo é exatamente o que seus realizadores afirmam: "uma oração à nossa maneira pela dignidade do homem". Querer proibir sua realização é uma atitude retrógrada, obscurantista, que não pode ser tolerada. Felizmente, são poucos os que pensam assim.

(Jornal da Tarde, 13/11/1992) 